\title{
Trend in Researches on Mathematics Achievement
}

\author{
Dr. Shyam Sundar Kushwaha \\ Asstt. Professor in Education, M.P. Government Degree College, Sikandara Rao (Hathras), U.P. India
}

\begin{abstract}
The quality of teaching and learning mathematics has been one of the major challenges and concerns of educators. If we consider a group of students, a few students are found to be high achievers on the one hand and a few are low achievers on the other. The question arises why such a difference in achievement appears? Is this difference due to certain factors? or Is there any single factor or host of factors which account for all the differences in mathematics achievement? These questions often appear in the minds of the Educators, Educationists and the Psychologists, but with hardly satisfactory answers. In this paper a comprehensive review of the related literature is done to identify the factors affecting the mathematics achievement of students. Review of the related literature reflect that the most preferential variables is in psychological category are Intelligence, Attitude towards Mathematics, Self-concept, Numerical Ability and Math Anxiety; among Social variables the variables which were considered very widely are Socio-economic Status, Parental Involvement \& Parents Education and among Biographical variables most frequently considered variable is Sex.
\end{abstract}

\section{Introduction}

In modern world, mathematics is being increasingly used in sciences, technologies, social science, education etc. With the use of computer and other devices there is a more emphasis in the mathematics. Though the world is more mathematically inclined, the majority of students in school feel it as more abstract. Though the teacher can teach it with the help of modern educational technological devices and more advanced effective methods of teaching, there is a poor performance of the students in the mathematics. Hence, there must be some factors like psychological, social and biographical affecting the learner in learning of mathematics at large.

In a study considering the factors of achievement in mathematics, one possibly ignores those aspects in which individuals differ from one another. The starting point may be achievement in mathematics itself where wide ranging variations occur from the point of non-performance to the point of outstanding achievement in it. If we consider a group of students, a few students are found to be high achievers on the one hand, and a few are low achievers on the other, while a sizable number of students always appear as moderate achievers. The question arises why such a difference in achievement appears when the school provides more or less uniform instructional and environmental facilities? Is this difference due to certain factors? Does this difference depend upon inherent qualities? or Is there any single factor or host of factors which account for all the differences in mathematics achievement ? These questions often appear in the minds of the Educators, Educationists and the Psychologists, but with hardly satisfactory answers. Various investigators have explored numerous factors which are found responsible for success or failure in the mathematics. Such factors seem to come under three general heads, which are shown in the following table -

Table 1: Associated Psychological variables and related research studies in relation to Achievement in Mathematics

\begin{tabular}{|c|l|l|}
\hline $\begin{array}{l}\text { S. } \\
\text { No }\end{array}$ & \multicolumn{1}{|c|}{ Variables } & \multicolumn{1}{c|}{ Researcher's Name by which the variables studied in relation to Mathematics Achievement } \\
\hline & Attitude towards & $\begin{array}{l}\text { Watson (1981), Miller, Linda, Herman (1981), Robert (1982), Mckethan (1982), Endsley (1984), } \\
\text { Nagialiankin (1988), Pal Ashutosh (1989), Jayraman (1989), Rajyaguru (1991), Nagailiankin (1991), } \\
\text { Bhaskaran (1991), Wohlgehager (1992), Rosaly (1992), Rodriguez (1992), Hariharan (1992), Armstrong } \\
\text { (1992), Miller (1993), Driver (1993), Bassa (1993), Thampurathy (1994), Chakalisa (1994), Thomous \& } \\
\text { wangu (1995), Stella \& Purushothaman (1995), Segars (1995), Jamison (1995), Hart (1995), Chism (1995), } \\
\text { Bragg (1996), Pruett (1997), Hunt (1997), Sumanagala (1998), Sriniwasan (1999), Toole (2001), Chen } \\
\text { (2001), Ganihar\& Wajihar (2009) and Choudhury \& Kumar (2009) }\end{array}$ \\
\hline 2 & Mathematics & $\begin{array}{l}\text { Bhushan and Sharma (1981), Annamal (1981), Rajput (1984), David and Michal (1984), Singh (1986), } \\
\text { Das (1986), Rajyaguru (1991), Kasat (1991), Nagialiankin (1991), Setia Seema (1992), Lalitha (1992), } \\
\text { Abdulmajeed (1992), Segars (1995), Whang (1997), Patel (1997), Kaliyan (1997), Sumangala (1998), } \\
\text { Arreita (1998), Glutting Joseph (2006) and Fernandez (2011) }\end{array}$ \\
\hline 3 & Math Anxiety & $\begin{array}{l}\text { Ashutosh (1989), Rajyguru(1991), Owens (1992), Vance (1993), Lafferty (1996), Maree et al. (1997), } \\
\text { Patel (1997), Piearey (1997), Soman (1997), Bruno (1999), Ma (1999), Abu-Hital \& Maher (2000), } \\
\text { Ho et al. (2000), Cates et al. (2003) and Maree et al. (2005) }\end{array}$ \\
\hline 4 & Self-Concept & $\begin{array}{l}\text { Singh (1986), Ashutosh (1989), Rangappa (1993), Sumangala (1998), Robert (1997), Pajares (1999), } \\
\text { Abu-Hital \& Maher (2000), Natali (2001) }\end{array}$ \\
\hline 5 & Study Habit & $\begin{array}{l}\text { Singh (1986), Biswal (1988), Ngialiankin (1988), Patel (1997), Jacobbi (1997), Arrieta, (1998) and } \\
\text { Choudhury \& Kumar (2009) }\end{array}$ \\
\hline 6 & $\begin{array}{l}\text { Khatoon(1988), Rajyaguru (1991), Abdulmajeed (1992), Miller(1993), Sumangala(1998) Rajani (2006) and Sethi } \\
\text { (2011) }\end{array}$ \\
\hline
\end{tabular}


Trend in Researches on Mathematics Achievement

\begin{tabular}{|c|l|l|}
\hline 7 & Numerical Ability & $\begin{array}{l}\text { Kasat (1991), Nagialankin (1991), Lalitha Bai (1992), Sumangala (1998), Kaliyan (1997) and Toole } \\
(2001)\end{array}$ \\
\hline 8 & $\begin{array}{l}\text { Achievement } \\
\text { Motivation }\end{array}$ & Rajput (1984), Bhaskaran (1988), Ashutosh (1989), Sanchez (1995) and Sriniwasan (1999) \\
\hline 9 & Cognitive Style & Narayan (1995), Hall (1993), Testone (1992), Bragg (1996) and Aseeri (2000) \\
\hline 10 & Self-Esteem & Strutchens (1993), Cashin (2001), Natali (2001) and Christon et.al (2001) \\
\hline 11 & $\begin{array}{l}\text { Interest } \\
\text { Mathematics }\end{array}$ & Singh (1986), Khatoon (1988), Kasat (1991) and Sitha, (2003) \\
\hline 12 & Test Anxiety & Somasundaran (1980), Patel (1997) and Ganihar \& Wajiha (2009) \\
\hline 13 & Reading Ability & Rangappa (1992), Testone (1992) and Arrieta (1998) \\
\hline 14 & $\begin{array}{l}\text { Problem Solving } \\
\text { Ability }\end{array}$ & Bure (1999), Arrieta (1998) and Thampurathy (1994) \\
\hline 15 & $\begin{array}{l}\text { Mathematical } \\
\text { Creativity }\end{array}$ & Biswal (1988), Thampuratly (1994) and Toole (2001) \\
\hline 16 & $\begin{array}{l}\text { Edu occu. } \\
\text { Aspiration }\end{array}$ & Nagialiankin (1991), Teague (1995) and Chen (2001) \\
\hline 17 & Personal Adjustment & Soman (1977), Singh (1986) and Setia (1992) \\
\hline 18 & Locus of Control & Sanchez (1995) \\
\hline 19 & Emotional Stability & Singh (1986) \\
\hline 20 & Confidence in Maths & Chakalisa (1994) \\
\hline
\end{tabular}

Table -2 : Associated Social variables and related research studies in relation to scholastic Achievement in Mathematics

\begin{tabular}{|l|l|l|}
\hline $\begin{array}{l}\text { S. } \\
\text { No }\end{array}$ & Variables & Researcher's Name by which the variables studied in relation to Mathematics Achievement \\
\hline 1 & SES & $\begin{array}{l}\text { Sharma \& Bhargava (1980), David \& Michal (1984), Leach \& Tunnechlifle (1984), Rajput (1984), Singh } \\
\text { (1986), Deshmukh(1988), Rajyaguru (1991), AbdulMajeed (1992), Kim (1992), Prabha Rashmi (1992), Setia } \\
\text { (1992), Leiker (1993), Thampurathy (1994), Segers (1995), Harris (1996), Piearey (1996), Patel (1997), Pruett } \\
\text { (1997), Grootenbore \& Hemmings (2007), Mustafa (2009) and Engin, Nuri \& Hulya (2010) }\end{array}$ \\
\hline 2 & School-Environment & $\begin{array}{l}\text { Testone (1992), Kim (1992), Thomous and Wangu (1995), Harris (1996), Well (1996), Pruett (1997), } \\
\text { Wong and Watkins (1998), Sriniwasan (1999), Yan, Amery \& Bruna (2006), Ibrahim, Serpil \& Ozer } \\
\text { (2009) and Gozde \& Giray (2010) }\end{array}$ \\
\hline 3 & Home-Environment & $\begin{array}{l}\text { Bonder et.al. (1982), Tsai and Walberg (1983), Marjoribank (1983), Dolan (1983), McGowan et.al. } \\
\text { (1984), Medrick and associates (1985), Javonovic (1992), Pruett (1997), Jacobbi (1997) and Chen } \\
\text { (2001) }\end{array}$ \\
\hline 4 & Parents Education & $\begin{array}{l}\text { Prabha (1992), Strutchens (1993), Santhamma (1996), Wells (1996), Patel (1997), Sriniwasan (1999) } \\
\text { O,Dwyer (2005) and Mustafa (2009) }\end{array}$ \\
\hline 5 & Parental Involvement & Rajyaguru (1991), Strutchen (1993), Wells (1996), Addington (1996) and Arnold \& Judith (1996) \\
\hline 6 & Father's Occupation & Rajyaguru(1991), Prabha (1992), Santhamma (1996) and Patel (1997) \\
\hline 7 & Income of Father & Rajyaguru (1991), Prabha (1992), Addington (1996) Mustafa (2009) \\
\hline 8 & Social Status & Rajyaguru(1991) and Thampurathy \& Girija (1999) \\
\hline 9 & Social Relations & Somasundaran (1980) and Singh (1986) \\
\hline 10 & Type of School & Thomous \& Wangu (1995) and Wells (1996) \\
\hline 11 & $\begin{array}{l}\text { Teacher's } \\
\text { Expectation }\end{array}$ & Turner (1993), Strutchens (1993) \\
\hline 12 & Social Maturity & Singh (1986) \\
\hline
\end{tabular}

Table-3 : Associated Biographical \& Instructional Variables and related research studies in relation to Achievement in Mathematics

\begin{tabular}{|l|l|l|}
\hline $\begin{array}{l}\text { S.N } \\
\text { o }\end{array}$ & Variables & Researcher's Name by which the variables studied in relation to Mathematics Achievement \\
\hline & & $\begin{array}{l}\text { Houston (1980), Ann Marle (1981), Becker (1981), Rule (1981), Sathiyagirirajan (1981), Soundararaja Rao } \\
(1981), \text { Heimann Vtefreyja (1982), Holland \& Sandler (1982), Jensen (1982), Endsley (1984), Carmichall } \\
(1986), \text { Koehler (1986), Metcaff (1986), Khatoon (1988), Rajyaguru (1991), Abdulmajeed (1992), Sucin } \\
(1992), \text { Testone (1992), Wohlgehager (1992), Bassa (1993), Driver (1993), Leiker (1993), Miller (1993), } \\
\text { Chakalisa (1994), Harvath (1995), Narayan (1995), Segars (1995), Thomous \& Wangu (1995), Arnold \& } \\
\text { Judith (1996), Cyrus (1996), Paria Debasis (1996), Patel (1996), Piearey (1996), Prakash \& Pandey (1996), } \\
\text { Wells (1996), Jacobi (1997), Kaliyan (1997), Pruett (1997), Marsh (1998), Matpass (1999), Sriniwasan } \\
(1999), \text { Toole (2001), Wang (2001), Singh \& Singh (2007), Choudhury \& Kumar (2009), Ganihar \& } \\
\text { Wajiha (2009), Khatoon \& Mahmood (2010) }\end{array}$ \\
\hline 2 & Gender & $\begin{array}{l}\text { Sharma (1979), Rajyaguru (1991), Rangappa (1993), Well (1996), Sriniwasan (1999) and Singh \& Singh } \\
\text { (2007) }\end{array}$ \\
\hline 3 & Method of Instruction & Prabha (1992), Testone (1992), Segars (1995) and Galddert (2001) \\
\hline 4 & Caste & Prabha (1992), Prakash \& Pandey (1996) \\
\hline 5 & Birth Order & Rajyaguru (1991) \\
\hline 6 & Teacher & Brodney (1991) \\
\hline 7 & Effectiveness & Sumangala (1998) \\
\hline
\end{tabular}


Aforesaid discussion advocates that achievement in mathematics is accounted for by number of psycho-socio-biographic variables of the students. The investigator reviewed the literature and found the voluminous studies on Mathematics Achievements in which Psychological, Social, Biographical and Instructional variables were studied simultaneously.

Further the tables 1, 2 and 3 respectively reflect that the most preferential variables of the investigation is in psychological category are Intelligence, Attitude towards Mathematics, Self-concept, Numerical Ability and Math Anxiety; among Social variables the variables which were considered very widely are Socioeconomic Status, Parental Involvement \& Parents Education and among Biographical variables most frequently considered variable is Sex.

The studies reviewed lead to the following types of trends -

1. Achievements in Mathematics in Relation to Variables Studied.

2. Tools Used for the Measurement of Mathematics Achievement and other Related Variables.

3. Methodology Adopted for Studying the Phenomenon of Mathematics Achievement.

\section{Achievement In Mathematics In Relation To Variables Studied}

It has been firmly established by now that Mathematics Achievement is influenced by psychological variables, social variables, biographical variables, instructional variables, and so on. Sufficient data are available which indicate relationship between these variables and Achievement in Mathematics. There are quite a few well-planned, well-designed multivariate studies which reveal many variables influence Achievement in Mathematics. But there is need to subdivide complex variables and find out how each of the sub-variables is related to the success in the Mathematics. To make a case, it may be noticed that SES which is a composite of sub-variables like parents income, father's educational level, mother's educational level, educational facilities available at home etc. has been found to fluctuate under different conditions in its relationship with pupils' success in the Mathematics.

Though an attempt has been made by a few researchers to consider a number of such sub-variables, it is felt that a greater emphasis should be laid on undertaking in-depth studies to analyze the relationship of Achievement in Mathematics to their interactive effects.

\section{Gender and Scholastic Achievement in Mathematics -}

Many research studies conducted in India and Abroad suggest the boys superiority over girls in educational Achievement in general and numerical ability in particular. Generally, it has been observed that male students have more knowledge and understanding of the Mathematical concepts and thinking in comparison to the females. In the Indian situation, it was found that boys' score in the Mathematics is higher than that of girls. The result of research studies conducted by Sathiyagirirajan (1981), Holland \& Sandler (1982), Khatoon (1988), Sucin (1992), Driver (1993), Bassa (1993), Leiker (1993), Chakalisa (1994), Thomous \& Wangu (1995), Narayan (1995), Matpass (1999), Patel (1996), Piearey (1996), Arnold \& Judith (1996), Paria Debasis (1996), Wells (1996), Pruett (1997), Kaliyan (1997), Jacobi (1997), Marsh (1998), Singh \& Singh (2007) and Khatoon \& Mahmood (2010) result support the conventional expectation of the boys superiority over the girls in learning outcomes of the Mathematics. Cyrus (1996) (boys have more ability in Mathematics), Narayan (1995) (boys scored higher on Numerical Ability), Becker (1981) also found the same result.

On the other hand, some researches reveal that the girls' superiority over boys' in the Mathematics Achievement viz; Kulkarni, Lal and Naidu (1970) in their survey found that girls belonged to Delhi and Mysore get more marks in comparison to boys. Endsley (1984), Wohlgehager (1992), Wang (2001) and Ganihar \& Wajiha (2009) found that girls achieved significantly higher score in the Mathematics than that of boys'.

There are some studies which reveal sex factor is non-effective eg. Rule (1981), Koehler (1986), Carmichall (1986), Rajyaguru (1991), Teston (1992), Abdulmajeed (1992), Miller (1993), Harvath (1995), Segars (1995), Sriniwasan (1999), Toole (2001) and Choudhury \& Kumar (2009) found in their studies that sex factor did not have an effect on the learning outcomes in the Mathematics.

Besides it, Houston (1980), Jensen (1982), Heimann Vtefreyja (1982), Carmichall (1986), Metcaff (1986) and Prakash \& Pandey (1996) found that males and females have significant difference on the Mathematics Achievement.

\section{Socio-Economic Status and Scholastic Achievement in Mathematics}

Among several sociological factors, S.E.S. of the child is one of the factor which requires constant examination. One of the intriguing aspects of students Mathematics Achievement is the S.E.S. of their parents.

It has become customary of educational research to treat S.E.S. as one of the effective factors of the Mathematics Achievement. Numbers of studies have clearly established a definite relationship between the S.E.S and learning outcomes in Mathematics. David and Michal (1984), Leach \& Tunnechlifle (1984), Rajput (1984), Singh (1986), Deshmukh(1988), Prabha Rashmi (1992), Setia (1992), Kim(1992), Leiker(1993), Pruett (1997), Segers (1995), Piearey (1996) and Patel (1997) have focused the positive contribution of the S.E.S. to the 
Achievement in Mathematics. Grootenbore \& Hemmings (2007), Mustafa (2009) and Engin, Nuri \& Hulya (2010) found that students from the higher S.E.S. groups scored more marks than the low SES groups.

On the contrary, many studies do not show any relationship between these two variables. Rajyaguru (1991), Abdulmajeed (1992), Thampurathy (1994) (Social Position), found low and negligible correlation between the S.E.S. and the Mathematics Achievement. They found that below a certain level, the marginal differences in socio-economic conditions as such couldn't contribute to Mathematics and Educational Achievement of the children. In the same way Bhargava (1980) did find very little rather negligible impact of the S.E.S. on the Mathematics Achievement.

In this connection, remark of Harris (1996) cannot be ignored. He found that the students of lower socio-economic status have more knowledge, understanding and application of the Mathematics in comparison with those students who have high socio-economic status because the students of the low socio- economic status get more opportunity of calculation in their day to day life. They have to go to market and they make transactions and hence they become experts in the mathematical calculations and applications.

\section{Intelligence and Scholastic Achievement in Mathematics}

Intelligence occupies a peculiar position in the study of school performance of Mathematics. A vast essay of research literature in Education and Psychology has brought it to common knowledge that intelligence as general ability, is an important contributory factor in the school Achievement. The level of intelligence truly makes a dominant difference in school's Achievement.

The Intelligence as an inherent unified and stable characteristic unequally found among the individuals. It is supposed that difference in learning outcomes in the Mathematics can be easily accounted for. It has been argued that more intelligent pupil is inherently capable of performing better in the examination and earns higher grades than less intelligent pupils. It is a common notion that students of high intelligence obtain better score in the Mathematics' test. Bhushan and Sharma (1981), Annamal (1981) and David and Michal (1984), found that the high intelligence group performs better than the low intelligence group in the Mathematics Achievement, specially in the area of computational skill. Materlis (1970) found that high intelligence made statistically significant gains in Mathematical Understanding than lower Intelligence groups. Kaliyan (1997) [Abstract Reasoning, Numerical Ability, Space Relation, Substitution of Symbols], Rajput (1984) and Nagialiankin (1991) [Numerical Ability, Abstract Reasoning, Space Relation], Rajyguru (1991), Lalitha (1992) [Numerical Ability, Abstract Reasoning, Non-language Reasoning], Setia Seema (1992), Sumangala (1998) [Numerical Ability, Numerical Reasoning, Ability to use Symbols, Spatial Symbols and Abstract Reasoning], Patel (1997), Whang (1997) [Reasoning Ability], Arrieta (1998), Segars (1995) [Student Ability] Glutting Joseph (2006) [Verbal Comprehension, Perceptual Reasoning, Working Memory and Processing Memory], Fernandez (2011) [Brain Hemisphericity] found positive relationship between the Intelligence and specific areas of the Mathematics Achievement. Similarly, Das (1986), Patel (1997), Kasat (1991) and Abdulmajeed (1992) found positive relationship between the Intelligence and the Mathematics Achievement.

But the long trail of consistent evidence found only a moderate correlation between measured Intelligence and Scholastic Achievement in Mathematics, gradually led to the acceptance of intelligence, as one of the several determinants. The fact is borne out in our everyday experience which shows that some pupils who impress us as fairly intelligent out of class situations, secure poor marks in the school and college examinations and some who appear dull in such situations, score high in the examinations. Thus although intelligence is a prominent and promising factor for the Achievement, but sometime it may be found that low intelligent or normal intelligent student can secure more marks than the high intelligence students due to some other reasons. Because learning outcome is affected by so many factors e.g. Study habit, home Environment etc. Wilson's (1978) study found that intelligence has no effect on the Mathematics Achievement of the boys and the girls.

It has also been observed that the high intelligence students sometimes fail to recall the formulas of the subject matter and hence they fail in the examination. Although such students have a very good understanding of the principles and they can apply those principles very effectively. On the contrary, it has also been observed that a student having low intelligence can crammed most of the principles of the Mathematics but he cannot apply those principles properly.

\section{Attitude towards Mathematics and Scholastic Achievement in Mathematics}

Attitude is surely a forceful determinant of the learning outcomes. Every student with similar abilities, differs in school attainment due to his attitude towards the subject. Several efforts have been made from time to time to satisfy the query of finding out the effect of Attitude toward Mathematics on learning outcomes in this subject.

It is a general observation that students having positive Attitude towards Mathematics get more marks in it in comparison with those students who have negative Attitude towards Mathematics. Much of the work has been done, based on the assumption that attitude affect Achievement recently - Miller (1993), Endsley (1984), Ashutosh (1989), Jayraman (1989), Nagailiankin (1991), Rajyaguru (1991), Wohlgehager (1992), Hariharan (1992), Rodriquez (1992), Armstrong (1992), Driver (1993), Bassa (1993), Segars (1995), Thomous \& Wangu 
(1995), Hart (1995), Stella \& Purushothaman (1995), Sriniwasan (1999), Choudhury \& Kumar (2009) and Ganihar\& Wajihar (2009) found in their studies that students' positive Attitude towards Mathematics is significantly related to Achievement in the Mathematics. Suydam and Weaver (1975) in their review of affective factors of Mathematics' learning mention that continued attention should be directed towards developing positive Attitude towards Mathematics Miller, Linda, Herman (1981) found a significant correlation between positive Attitude towards Mathematics and Mathematics computational skill.

But sometimes, it has been observed that students, who have no positive Attitude in Mathematics, are able to get good marks in the Mathematics. In other words, it may be stated that attitude has no effect on the learning outcomes in the Mathematics. (Ngailiankin, 1988). Aiken (1976) in reviewing studies, examining the relationship between attitude and Achievement in Mathematics usually found low correlation which did not always reach the level of statistical significance. Watson (1981), Robert (1982) and Mckethan (1982) have conducted studies and found that attitude had no effect on the outcomes of the Mathematics.

With the help of above-mentioned studies it is clear that the relationship between Attitude and Mathematics Achievement, however, is not clearly defined. At present, no bodywork to support such a relationship, it is necessary to find out the relationship on the scientific basis.

\section{Home Environment and Scholastic Achievement in Mathematics}

Today, we find an immense increase in the number of problem children. Indiscipline, no compliance, delinquency and character disorders and failure in academic Achievement are increasing by leaps and bounds. The parents do not know how to treat their children so that they may develop themselves adequately. Therefore, what is the most required thing, today, is that parents should be aware of the influence of the Home Environment on academic development of the children.

A glance through the review of related literature reveals that students Achievement in Mathematics and Home Environment are linked together. This has been supported by psychological theories of cognitive development, learning theory of development of Robert Seers and many others. This rationale provides a basis for finding out relationship between the Achievement in Mathematics and Home Environment. Some evidence of this is already available in the research literature. A few researchers have shown that the lack of parental care, lack of control lead to maladjustment and ultimately lead to poor Achievement in Mathematics, while other researches have shown that the rejection might lead to good social adjustment outside the Home and ultimately lead to good Achievement in Mathematics. According to findings of some researchers physical and verbal control lead to maladjustment and non-compliance which lead to greater degree of anxiety and this anxiety ultimately effects the Achievement in Mathematics. The studies largely demonstrate that Achievement in Mathematics is linked with the Home Environment in various ways. Dolan (1983), McGowan and associates (1984), Medrick and associates (1985), Bonder \& his associates (1982), Marjoribank (1983) and Tsai \& Walberg (1983) have found in their studies that the academic Achievement of the children is definitely influenced by the Home Environment, particularly the educational Environment of the Home. Pruett (1997), Jacobbi (1997) and Chen (2001) found that the Achievement in Mathematics is significantly influenced by Home physical and educational Environment.

In India, so for the investigator knows, not a single study has, however, been conducted which would have shown, which characteristics of Home Environment are related to Achievement in Mathematics and in what manner. Several researches in many other countries have used this rationale. But their findings are not conclusive.

\section{Locale and Scholastic Achievement in Mathematics}

India is predominantly an agricultural nation with the majority of the population living in rural areas. On the whole, people in urban areas enjoy more educational facilities than those in the rural areas. Apart from this, it is generally felt that parents, in the urban areas because of their occupational status and education, are likely to take more interest in the education of their children than their counter parts in the rural areas. As such, it is hypothesized that the urban school students are superior to the rural children in Mathematics Achievement.

Rangappa (1993), Well (1996) and Singh \& Singh (2007) made an investigation and found that urban students are better than rural students in Mathematics Achievement. But this fact is not always true as Sharma (1979) and Sriniwasan (1999) found that rural urban population has no significant difference in Mathematics Achievement. There are also some studies in which no particular results can be drawn, because the findings indicate that both groups are good in different case. In some cases rural students performed better whereas in some cases urban students did well.

Thus, the results show all the possible combination and hence one cannot make any categorical statement regarding the urban students superiority or otherwise in vis-à-vis Mathematics Achievement for the students.

\section{Institutional Climate and Scholastic Achievement in Mathematics}

One of the important variables which may have some bearing on the students' Achievement is the Institutional Climate or School Environment. In India school types vary from state to state considerably viz- 
government schools and non-government schools, private managed schools, government-aided schools etc. But for the present research the schools have been divided into two broad categories- good schools, having good institutional climate and bad school, having bad institutional climate.

It is a general observation that students, having good institutional climate, get more marks in comparison with those students who have bad institutional climate. Much of the work has been done, based on the assumption that institutional climate affects Mathematics Achievement. Recently- Thomous and Wangu (1995), Pruett (1997), Testone (1992), Kim (1992), Harris (1996), Well (1996), Wong and Watkins (1998), Ibrahim, Serpil \& Ozer (2009) and Gozde \& Giray (2010) found in their studies that the Institutional Climate is significantly related to the Achievement in Mathematics. But sometimes it has been observed that students, who have bad institutional climate, are able to get good marks in the Mathematics. In other words, it may be stated that the institutional climate has no effect on the learning outcomes in this subject. Sriniwasan (1999) in his study found that institutional climate have no effect on the outcomes of Mathematics. Yan, Amery \& Bruna (2006) found that Mathematics Achievement was highly related to outside of the school factors than that of the school associated factors.

With the help of above-mentioned studies it is clear that the relationship between the institutional climate and the Mathematics Achievement, however, is not clearly defined. But as there was, at present nobody works to support such a relationship, it is necessary to find out the relationship on the scientific basis.

\section{Math Anxiety and Scholastic Achievement in Mathematics}

As far as empirical evidence of the relationship between mathematics anxiety and achievement is concerned, correlations have been found to be negative (the higher the anxiety, the lower achievement tends to be). (Cates et al., 2003; Ho et al., 2000; Ma, 1999; Maree et al., 1997; Maree et al., 2005 Ashutosh (1989), Rajyguru (1991), Vance (1993), Lafferty (1996), Soman (1997), Piearey (1996) Bruno (1999). The consistency of the magnitude of the relationship between the two constructs has been addressed by Hembree (cited in Ma, 1999) in a meta-analysis who found the average correlation between the mathematics' anxiety and the achievement of mathematics to be in the order of -0.3. Ma (1999), in his meta-analysis of 26 studies related to learners (at school) found the common population correlation to be -0.27 . Contradictory results have however, also been reported, e.g. a positive relationship between anxiety and performance, i.e. as performance increases, so does anxiety and vice versa $(\mathbf{M a}, 1999)$. On the contrary, many studies (Patel, 1997; Owens 1992; Abut-Hital \& Maher, 2000) do not show any relationship between these two variables.

\section{Other Factors and Scholastic Achievement in Mathematics}

Scholastic Achievement in Mathematics is affected by a number of factors. Among them some factors can be identified very clearly such as SES, Sex, Attitude Towards Mathematics, Intelligence etc. But some other factors like Numerical Ability (Kasat, 1991; Nagialiankin, 1991; Lalitha Bai, 1992; Sumangala, 1998; Kaliyan, 1997 and Toole, 2001), Achievement Motivation (Rajput, 1984; Bhaskaran, 1991; Ashutosh, 1989; Sriniwasan, 1999 and Sanchez, 1995), Study Habit (Singh, 1986; Biswal, 1988; Nagialiankin (1988); Patel,1997; Jacobi, 1997; Arrieta, 1998 and Choudhury \& Kumar 2009), Self-Concept (Singh, 1986; Ashutosh, 1989; Rangappa, 1993; Sumangala, 1998; Robert, 1997; Marsh, 1998; Pajares, 1999; Abu-Hilal \& Maher, 2000 and Natali, 2000), Self-esteem (Strutchens, 1993; Cashin, 2001; Natali 2001 and Christon et.al. 2001), Locus of Control (Sanchez, 1995), Cognitive Style (Narayan, 1995; Hall, 1993; Testone, 1992; Bragg, 1996 and Aseeri, 2000), Reading Ability (Rangappa, 1992; Testone,1992 and Arrieta 1998), Mathematical creativity (Biswal , 1988; Thampurathy, 1994 and Toole, 2001) Mathematical Aptitude (Khatoon,1988; Rajyguru ,1991; Abdulmajeed, 1992; Miller, 1993; Sumangla, 1998; Rajani, 2006 and Sethi, 2011), Emotional stability (Singh, 1986), Interest in Mathematics (Singh, 1986; Khatoon, 1988; Kasat, 1991 and Sitha, 2003), Educational \& occupational Aspiration (Nagialiankin, 1991; Teague, 1995 and Chen, 2001), Personal adjustment (Soman, 1977; Singh, 1986 and Setia, 1992), Social Maturity (Singh, 1986), Teacher's Expectation (Turner, 1993 and Strutchens, 1993), Caste (Prabha, 1992; Prakash \& Pandey, 1996), Birth order (Rajyaguru, 1991), Method of Instruction (Prabha, 1992; Testone, 1992; Segars, 1995 and Galddert, 2001), Teacher Effectiveness (Brodney, 1991), Family Income (Mustafa, 2009), Parents Educational Level (Mustafa, 2009; O,Dwyer, 2005; Well, 1996 and Sriniwasan, 1999), Problem Solving Ability (Choi Bure, 1999; Arrieta, 1998 and Thampurathy, 1994), Textanxiety (Patel, 1997; Ganihar \& Wajiha, 2009) and Parental Involvement (Rajyaguru, 1991; Strutchen, 1993; Wells, 1996; Addington, 1996 and Arnold \& Judith, 1996) can not be recognized clearly.

\section{Tools Used For The Measurement Of Achievement In Mathematics And Other Related Variables}

Except for a few well-known foreign tools which continue to be used, the researchers in India have increasingly started using tools developed by them. This is, of course, quite encouraging. But a note of caution has to strike when a researcher develops a tool for his study by merely pooling some items and does not subject it to the sophisticated techniques of tools construction, the result would then be obviously of poor quality research. 


\section{Methodology Adopted For Studying The Phenomenon Of Achievement In Mathematics}

A particular trend that emerges in this aspect of research is that a large number of researches have used descriptive research methodology. The research studies reviewed in this chapter indicate that most of the researchers select some variables to study their relation with Achievement in Mathematics, select suitable tools, administer them to some available sample and collect the required data. Collected data have been mostly subjected to correlation techniques or at least to analysis of variance. Even the sophisticated techniques of factor analysis and co-variance have rarely been used by them so far so good, but structural equation modeling has not been used by any researcher in India. In some researches, even the tools used, are not standardized ones. The investigators have developed one or more tools for collecting data whether or not this is one of the objectives of their studies.

Current trend on the phenomenon of Achievement in Mathematics has been to use Post-Facto Research Methodology. The phenomenon of the Achievement in Mathematics will acquire more clarity of experimental method is also used for this purpose. The findings of the descriptive research would provide a sound base to select the most effective variable and frame hypothesis accordingly.

\section{References}

[1]. Abdulmajeed, Ahmed Sultan (1992). A study of mathematics achievement of grade XII students on GSCE in Irbid, Jordan in relation to their gender, intelligence, mathematical thinking and socio-economic status. reff. in M.B. Buch (Ed.), Fifth Survey of Educational Research, NCERT.

[2]. Abu Hital \& Maher, M. (2000). A structural model for predicting mathematics achievements its relation with anxiety and selfconcept in mathematics. Psychological Reports, Vol. 86(1) : 835-847.

[3]. Addington, D.G. (1996). Effect of parental involvement on mathematics achievement at eight, tenth and twelfth grades. P.hd. Virginia University. Ref in Dissertation Abstract International, vol.57, no.-1, May 1997.

[4]. Ann Marle, Rule (1981). A study of the diagnostic/ prescriptive process of teaching Mathematics and change achievement in Mathematics for 4th, 6th grade Inner city school students. Reff in Dissertation. Abstract International, Vol. 42, No. 5, p. 2009.

[5]. Annamal, Driscal (1981). The effect of tension control training on mathematics and reading achievement with elementary school children. Reff in Dissertation Abstract International, vol. 42, No. 9 1982, p.3853.

[6]. Armstrong, W.L. (1992). A descriptive study of the interrelationship of parents, teachers and students attitude towards mathematics and student achievement of selected eight grade students in the Englewood unified school district. Ed.D. university of southern California. Ref in Dissertation Abstract International, Vol. 54, no.4, Oct 1993.

[7]. Arnold, J. \& Judith, E. (1996). A study to determine the effect of dissect parental environment of students mathematics achievement in grades three through fifth Ed.D. wayne state university. Ref in Dissertation Abstract International, vol. 57 no., 12 Jun 1997.

[8]. Arrieta, I.M. (1998). A causal model of mathematics performance. Encenanza-de-las cieneias. Mar, Vol 16(1): 63-71.

[9]. Aseeri. M.M. (2000). An investigation of the relationship between students formed level of Cognitive Development, learning style and mathematics achievement in eleventh grade in Abha Saudi Arabia. Ph.D., Ohio University, ref in Dissertation Abstract international; Vol. 61, No. 7, Jan. 2001.

[10]. Ashutosh, Pal (1989). A critical study of some affective outcomes of the students as predictors of their mathematical ability. Ph.D., (Edu.) Uni. of Kahyani. reff. in M.B. Buch (Ed.), Fifth Survey of Educational Research, NCERT.

[11]. Bassa, M.M. (1993). An Exploration of differences in attitudes towards mathematics in the sixth-grade by gender race and achievements levels Ed.D. Memphis state University ref in Dissertation Abstract International, Vol. 54, no.- 8,Feb.

[12]. Becker (1981). Differential treatment of females and males in Mathematics classes. Journals of Research in Mathematics, Vol,12, p. 40.

[13]. Bhaskaran, K. (1991). Achievement-motivation, attitude towards problem-solving and achievement in mathematics of Standard X students in Devakottai Educational District. Ph.D.,(Edu.), Alagappa Univ. reff. in M.B. Buch (Ed.), Fifth Survey of Educational Research, NCERT.

[14]. Bhushan, Anand and Sharma, Usha (1981). The effect of personality variables and intelligence on the performance of high school students in Mathematics, Asian Journal of Psychological and Education. Vol.7, No.2, p. 44.

[15]. Biswal, J. (1988). Creativity in mathematics as a function of study habits and pupils' perception of teachers' impression about their performance in mathematics. Ph.D.(Edu.), Utkal Universiy. reff. in M.B. Buch (Ed.), Fifth Survey of Educational Research, NCERT.

[16]. Bonder et.al. (1982). Effects of home environment, SES, and maternal test scores on mathematics achievement. Journal of Educational Research, 89, 305-315

[17]. Bragg, Martha Farmer (1996). The effect of transactional writing on college algebra students achievements and attitude. Ph.D, North Carolina University. Ref in Dissertation Abstract International, vol 57, no. 11, May 1997.

[18]. Broadney, S.B. (1991). The relationship between student achievement, student attitude, and student perception of teacher effectiveness and the use of Journal as a leaning tool in mathematics. Ph.D. The University of Southern Mississippi. Ref in Dissertation Abstract International, Vol. 54, No. 8, Feb 1994, p.2884 A.

[19]. Bruno, L.N. (1999). Predicting mathematics performance. The science and engeneering.1999 Feb, Vol. 59(8-B).4497.

[20]. Carmichall, Henry Albert Aptha (1986). The understanding of mathematics concepts and skills among unschooled Nape children of Niger state Nigeria. Dissertation Abstract International, Vol. 48, no. 5, p -1140.

[21]. Cashin, S.E. (2001), Effect of Mathematics self-concept, perceived self-efficacy and attitude towards statistics on statistics achievement. Ph.D. Southern Illinois University. Reff in Dissertation Abstract International. Vo. 61 No. 8, Feb. 2001.

[22]. Cates et al. (2003). The effect of mathematics anxiety on post-secondary developmental students as related to achievement, gender and age. Inquiry, $9,1$.

[23]. Chakalisa, P.A. (1994). Relationship of student gender, teacher experience and setting to students achievement and attitude towards mathematics in Botswana community junior secondary schools. Ph.D Ohio University. ref in Dissertation Abstract International. Vol. 54,No. 12, p. 4340-A.

[24]. Chism, Patricia J.R. (1995). Applied mathematics' and algebra students' mathematics and attitude. Ed. D. Univ. of Georgia, 1994. ref in Dissertation Abstract International, vol. 55 no. 9, March 1995.

[25]. Choi, Bure (1999). A structural model of problem-solving ability, self-efficiency, effort, worry and achievement in Calculus. Dissertation Abstract International section A : Humanities and social sciences. 1999 Jul, Vol.-60 (1A) : 64.

[26]. Choudhury, Ranjana and Kumar, Dhiraj (2009). Influence of Attitude towards mathematics and study habit on the achievement in mathematics at the secondary stage. International Journal of Engineering Research and Applications. Vol.2, issue-6, pp.192-196. 
[27]. Christon, C., Phillipon, G. and Menon, M.E. (2001). Preservice to teachers, self-esteem and mathematics achievement. Contemporary-Education psychology, 2001 Jan, Vol. 26(1) : 44-60.

[28]. Cyrus, K.R. (1996). Causal explanations for mathematics performance given by low socio-economic status African-American mothers and their children. Ph. D University of Florida. Ref in Dissertation Abstract International, vol. 57. no. 9, March 1997.

[29]. Das, S. (1986). 'Peer influence and educated aspiration of secondary school students, a study in relation to their academic achievement.' Unpublished Ph.D. (Education). M.S. University.

[30]. David J. Leach and Michal R. Tunnechliffe (1984). The relative influence of time variables on Primary Mathematics achievement. The Australian Journal of Education, Vol. 28, No.2, p. 126.

[31]. Deshmukh, Veena (1988). Some temperamental correlates of mathematics learning. Ph.D., (Edu.), Nagpur Univ., reff. in M.B. Buch (Ed.), Fifth Survey of Educational research, NCERT.

[32]. Dolan, Lawrance (1983). The prediction of reading achievement and self-esteem from an Index of Home Education Environment. A study of urban Elementary Students: Measurement and evaluation in Guidance, 16:2, 86-94.

[33]. Driver, R.T. (1993). Gender deference in mathematics. A study of relationship of the attitudes of fifth eight and tenth grade male female students as measured on the Fennema-Sherman mathematics attitude scales with student achievement and practices Ph.D. Kansas state university, reff. in Dissertation Abstract International, Vol. 54 no.4 Nov.1993.

[34]. Endsley, James Glenn (1984). The relationship of cognitive preference, sex and attitude on achievement scores in a first year Algebra course, Dissertation Abstract International, Vol.54, no. 1 p. 107.

[35]. Fernandez, Sanny F. (2011). 'Brain Hemisphericity \& Mathematics Achievement of High School Students' (ED537715). Online Submission, M.A. Thesis, West Visayas State University.

[36]. Gaeddert, Terri J (2001). Using Accelerated Math To Enhance Student Achievement in High School Mathematics Courses. (ED463177) Online Submission of Dissertation.

[37]. Glutting, Joseph J.; Watkins, Marley W.; Konold, Timothy R. and McDermott, Paul A. (2006). Distinctions without a Difference: The Utility of Observed versus Latent Factors from the WISC-IV in Estimating Reading and Math Achievement on the WIATII (EJ758172). Journal of Special Education, vol.40, no.2, pp.103-114.

[38]. Grootenboer, Peter and Hemmings, Brian (2007). Mathematics Performance and the Role Played by Affective and Background Factors (EJ788375) Mathematics Education Research Journal, vol.19, no.3, pp3-20.

[39]. Hall, L.A. (1993). A critical exploration of learning style preferences and the math achievement of chapter-I middle school students: Administrative and instructional implications. Ed.D. Oklanoma state University Ref in Dissertation Abstract International, Vol.54, no.10, April 1994.

[40]. Hariharan, D. (1992). Attitudes of High School students towards homework and their achievement in mathematics. M.Phil.(Edu.), Madurai Kamaraj Univ., reff. in M.B. Buch (Ed.), Fifth Survey of Educational research, NCERT.

[41]. Harris, L.G. (1996). The relationship between classroom climate and academic achievement in reading mathematics and language for a group of fourth-grade suburban elementary students. Ed.D. The University of Mmhis. Ref. In Dissertation Abstract International, Vol.57, no.1 July 1996.

[42]. Hart, Kathleen Mary (1995). Mathematics achievement and attitude of nine and ten years olds, effects of mathematical games and puzzles. Ref in Dissertation Abstract International, vol. 37, No. 7-8, p 4932.

[43]. Harvath, Mattew John, (1995). A comparative study of the achievement and attitudes change as a result of individualized and nonindividualized Mathematics teaching methods in the seventh, eighth and ninth grades, Dissertation. Abstract International, Vol 36, No8, p. 4991.

[44]. Heimann, Vtefreyja (1982). The sex of secondary school Principals as a factor in Mathematics achievement of students. Dissertation Abstract International, Vol. 42, No.9, p. 3825.

[45]. Ho et al. (2000). Cognitive style and mathematics anxiety among high-school students. Psychology in the Schools, 25(1), 75-83

[46]. Holland, R. and Sandler, B. (1982) The classroom climate, a chilly for women, Washington D C project on the status and education of women association of American college.

[47]. Houston, Gustie and Marie Rice (1980). An investigation of the relationship among the affective, parental, social and peer influence on achievement in Mathematics of male and females among black, anglo and chicano adolescents, Dissertation. Abstract International, Vol.40, No.11, p. 5769.

[48]. Hunt, Beverly Thornhill (1997). The effect of English immersion mathematics classes on the mathematics achievement and aspirations of eight-grade Spanish-speaking LEP students Ph.D. Univ. of North Texas. Ref in Dissertation Abstract International, vol. 57, no. 11, May 1997.

[49]. Ibrahim Demir, Serpil Kilıç and Ozer Depren (2009). Factors affecting Turkish students' achievement in mathematics. US-China Education Review, ISSN 1548-6613, USA Jun. 2009, Volume 6, No.6 (Serial No.55)

[50]. Jacobi, M. Donna (1997). Teacher's professional preparation, classroom instructional practice and student mathematics achievement Ph.D. The Univ. of New Mexico. Ref in Dissertation Abstract International, Vol. 57, no. 10 , April 1997.

[51]. Jamison M.G. (1995). An exploration of extra and classroom variables for three measure of college mathematics achievement. Ph.D, Virginia polytechnic and state university, ref in Dissertation Abstract International, vol. 55, no. 9, March 1995.

[52]. Javonovic (1992). The role of Individual psychological and familiar characteristic in boys and girls Psychological and familial characteristics in boys and girls mathematics achievement. Across-cultural comparison. Ph.D., The ref in Dissertation Abstract International, Vol. 53, No.- 3 Sept. 1996.

[53]. Jayaraman, V. (1989). Some correlates of students' achievement in mathematics at Standard X level in Devakottai Educational District. M.Phil., (Edu.) Alagappa Univ., reff. in M.B. Buch (Ed.), Fifth Survey of Educational Research, NCERT.

[54]. Jensen, Slavall Joyee (1982). The effect of summer races on the retention of reading and mathematics achievement of third and fifth grade students in a compensatory education programme, Dissertation Abstract International, Vol.42, no. 12, p.5020.

[55]. Kaliyan (1997). 'A study of certain ability correlates of secondary school mathematics achievements measures using Bloom's Taxonomy Cognitive domain.’ Ph.D Edu, Univ. of Kerala.

[56]. Kasat, B.S. (1991). In-depth study of the causes of the large failures in mathematics at S.S.C. examination of Marathi medium high school students in Palghar Tahsil. M.Phil., (Edu.) Pune; Indian Institute of Education. reff. in M.B. Buch (Ed.), Fifth Survey of Educational Research, NCERT.

[57]. Khatoon, F. (1988). A study of mathematical aptitude among boys and girls and its relationship with interests and vocational preferences at the secondary school level. Ph.D., (Edu.) Osmania Univ. reff. in M.B. Buch (Ed.), Fifth Survey of Educational Research, NCERT.

[58]. Khatoon, Tahira and Mahmood, Sadia (2010). Mathematics Anxiety Among Secondary School Students in India and its Relationship to Achievement in Mathematics European Journal of Social Sciences - Volume 16, Number 1 (2010)

[59]. Kim, L.Y. (1992). Factors affecting student outcomes : A school level analysis of the 1990 NAEP mathematics trial state assessment Ph.D. University of southern California. Cited in Dissertation Abstract International, Vol.53, no.12 June 1993. 
[60]. Koehler, M.C. (1986). Effective Mathematics teaching and sex related differences in Algebra classes. Ref in Dissertation Abstract International. vol. 46, No. 10, 1986, p.2953.

[61]. Lafferty, Joseph Fancis (1994). The link among mathematics text, students achievement and students, mathematics anxiety; A comparison of the incremented development and traditional texts. Ed.D, Widner University. Ref in Dissertation Abstract International, vol. 56, No.8 Feb. 1996.

[62]. Lalitha Bai, T.K. (1996). A comparative study of the cognitive factor structures of the high, average and low-achievers in secondary school mathematics. Ph.D., (Edu.) Univ. of Kerala. reff. in M.B. Buch (Ed.), Fifth Survey of Educational Research, NCERT.

[63]. Leach, David and Tunnechlifle, M.R. (1984). The relative influence of time variables on primary mathematics achievement. Ref in Dissertation Abstract International, vol. 28, No.2, 1984, p.126.

[64]. Leiker, V.C. (1993). The relationship between an integrated Learning system, reading and mathematics achievement higher order thinking skills and certain demographic variables. Ed.D. Baylor Univ. Ref. In Dissertation Abstract International, Vol.54, no.11, May 1994.

[65]. Ma, X. (1999). A meta-analysis of the relationship between anxiety towards mathematics and achievement in Mathematics. Journal for Research in mathematics Education, 30(5),520-540

[66]. Maree et al. (1997). Predictors of math anxiety and its influence on young adolescents' course enrollment intentions and performance in mathematics. Journal of Educational Psychology, 82, 60-70.

[67]. Maree et al. (2005). The relationship of mathematics self-efficacy beliefs to mathematics anxiety and performance. Measurement and Evaluation in Counseling and Development, 24(1), 4-11.

[68]. Marjoribank, K. (1983). Occupational Status, Family Learning Environment and Children Achievement. Alberts Journal of Educational Research, $29: 2,110-112$.

[69]. Marsh, H.W. (1998). Longitudinal structural equation models of academic self-concept and achievement: Gender differences in the development of math and English construct. American Educational Research Journal. vol. 35(4) : 705-738.

[70]. Martin, J.A. (1987). Structural Equation Modeling : A guide for the perplexed, Child Development. 58, 33-37.

[71]. Matpass, J.R. (1999). Self-regulation, goal orientation, self-efficiency, worry and high stakes maths achievement for mathematically gifted high school students. Roeper - review, 1999 May-June, Vol.21(4) : 281-288.

[72]. McGowan, R.J. and Johnson, D.L. (1984). The mother child relationship and others antecedents of academic performance : A Causal Analysis. Hispanic Journal of Behavioural Science, 6: 3, 205-224.

[73]. Mckethan, Lillion Dolares, (1982). Attitudinal and achievement comparison of Mathematics deficient Lincoln Univ. Freshmen, Resulting from structured peer tutoring verses no peer tutoring Mathematics. Dissertation Abstract International, Vol.43, No.3.

[74]. Medrick, B. R., Baker, R.L. and Hocever, D. (1985). Family Size \& Birth Order Correlates of Intellectual, Psychological and Physical Growth. Merrill-Palmore Quarterly, 31: 1, 67-84,

[75]. Metcaff, B.H. (1986). The Mathematics achievement of students thought by traditional and competency based approaches, ref, in Dissertation Abstract International. Vol. 46, no. 12, 1986, p.3641.

[76]. Miller, Linda, Herman, (1993). Time relationship of selected variables in Mathematics achievement of teacher education applicants. Dissertation. Abstract International, Vol.41, No. 8, p. 3359.

[77]. Mustafa, Yavuz, (2009). Factors that Affect Mathematics-Science (MS) Scores in the Secondary Education Institutional Exam: An Application of Structural Equation Modeling (EJ858932). Educational Sciences: Theory and Practice, vol.9, no.3, pp.1557-1572.

[78]. Nagialiankin, Caroline. (1991). A study of selected variables associated with achievement in mathematics. Ph.D., (Edu.) NorthEastern Hill Univ. reff. in M.B. Buch (Ed.), Fifth Survey of Educational Research, NCERT.

[79]. Narayan, Hota (1995). Sex differences in mathematical and verbal reasoning ability among field independent and field dependent individuals. Journal of Community Guidance and Research. vol. 12(3). 205-214.

[80]. Natali, M, (2001). A comparative and interpretive study of the effect of traditional multiple-choice assessment with generative alternatives assessment on state anxiety and mathematics achievement of sixth grade students. Ph.D. St. Johns University. ref in Dissertation Abstract International. vol 62, no. 03.

[81]. O'Dwyer, L. M. (2005). Examining the variability of mathematics performance and its correlates using data from TIMSS '95 and TIMSS '99. Educational Research and Evaluation, 11(2), 155-177.

[82]. Owens, A.R. (1992). The relationship between selected effective and cognitive variables to academic achievement and persistence with peer tutoring. Ed.D. University of Georgia ref. In Dissertation Abstract International, Vol.50(1). July 1993.

[83]. Pajares, F\& Graham Laura (1999). Self-efficacy, motivation constructs and mathematics performance of entering middle school students. Contemporary Educational Psychology. vol. 24(2) pp. 124-139

[84]. Pal, Asutosh. (1989). A critical study of some affective outcomes of the students as predictors of their mathematical ability. Ph.D., (Edu.) Uni. of Kahyani. reff. in M.B. Buch (Ed.), Fifth Survey of Educational Research, NCERT.

[85]. Paria, Debasis. (1996). A comparative study of mathematical achievement of boys and girls at secondary level. Journal of Centre for Pedagogical Studies in mathematics, 6-8.

[86]. Patel, Chatur P. (1996). General anxiety : Defensiveness and the achievement in mathematics of the secondary school students. The Progress of Education, Vol. IXX(8), 189-192.

[87]. Patel, Chatur, P. (1997). Impact of test-anxiety and test-defensiveness on the achievement in mathematics of secondary school students. The progress of Education, Vol. LXXI(6), 141-144.

[88]. Piearey, R.K. (1996). The relationship between maths anxiety, cerebral hemispheric dominance and final course grade of students in college algebra Ed.D. East -Texas state University cited in Dissertation Abstract International, Vol.57 no.7 Jan. 1997.

[89]. Prabha, Rashmi. (1992). An investigation into the effectiveness of programmed mathematics in relation to some socio-academic variables. Ph.D., (Edu.) Patna Univ. reff. in M.B. Buch (Ed.), Fifth Survey of Educational Research, NCERT.

[90]. Prakash, Ved and Pandey, Saroj (1996). Influence of demographic variables on learners' achievement : A trend analysis of DPEP states. Indian Educational Review, Vol. 31(1). 36-46.

[91]. Pruett, J.A. (1997). The relationship of gender bias to mathematics and science achievement. Ed.D. Grambling state University cited in Dissertation Abstract International, Vol.57 no.7 Jan $1997: 2901$ A.

[92]. Rajani (2006). 'Teacher-parental support study habits, aptitude for and attitude towards mathematics as predictors of mathematics achievement.' Unpublished Doctoral Thesis in Education, Punjab University, Chandigarh

[93]. Rajput, A.S. (1984). Study of Academic Achievement of Students in Mathematics in Relation to their Intelligence, Achievement Motivation and Socioeconomic Status, Ph.D. (Edu.), Pan. Univ. reff. in M.B. Buch (Ed.), Fourth Survey of Educational Research, NCERT.

[94]. Rajyaguru, Mahesh S. (1991). A comparative study of over - and underachievers in mathematics, Ph.D., (Edu.), Bhavnagar Univ. reff. in M.B. Buch (Ed.), Fifth Survey of Educational Research, NCERT.

[95]. Rangappa, K.T. (1993). Effect of reading ability on mathematical performance. Psycho-Lingua, Vol. 23(1), 25-30.

[96]. Robert (1982). Parent and student attitudes towards mathematics as they relate to third grade mathematics. Journal of Instructional Psychology, 20 (2), 96-102. 
[97]. Robert, Lee Johnson, (1997). The effect of the teaching Algebra on the maintenances and developing of arithmetic skill. Dissertation. Abstract International, Vol.31,No,10, p. 5079.

[98]. Rodrigue, R.S. (1992). Hispanic student achievement, program of study and gender differences in attitude exploratory study. Ed.D. University of Massachusetis cited in Dissertation Abstract International, Vol.53 no.7, Jan 1993.

[99]. Rosaly, A (1992). The relationship between attitude of students towards mathematics and achievement. M.Phil., (Edu.) Madurai Kamaraj Univ. reff. in M.B. Buch (Ed.), Fifth Survey of Educational Research, NCERT.

[100]. Rose \& Medwey (1984). Teacher locus of control. Journal of Education Research; 79 (1).

[101]. Rule, Ann Marie, (1981). A study of the diagnostic/ prescriptive process of teaching Mathematics and change achievement in Mathematics for 4th, 6th grade Inner city school students. Dissertation. Abstract International, Vol. 42, No. 5, p. 2009.

[102]. Sanchez, L.W. (1995). Influence of achievement motivation \& prior mathematics achievement on lows of control and mathematics performance as impacted through written instructions. Ph.D. Univ. of Hawaii ref. In Dissertation Abstract International, Vol.55 no.11

[103]. Santhamma, Raju (1996). Mathematical Aptitude in relation to socio-familial variables. Experiments in education, vol XXIV, 13-19.

[104]. Sathiyagirirojan, S. and Soundararoja Rao, T.R. (1981). A comparative study of achievement of pupils of standard X in English and composite mathematics, Journal of Education Research and Extension, Vol. 4, no. 2, p.55.

[105]. Segars, J.E. (1995). Selected factors associated with eight-grade mathematics achievement. Ed.D. Mississippi state University, 106 pp, ref. in Dissertation Abstract International,Vol.56 no.3 Sept.

[106]. Sethi, Neetu (2011). A study of academic achievement in mathematics in relation to mathematical aptitude of high school students. Golden Research Thoughts. Vol.1, issue-ii, pp. 1-4.

[107]. Setia, Seema. (1992). Socio-psychological and educational factors of differential learning rate in modern mathematics at the senior secondary stage. Ph.D., (Edu.) Panjab Univ. reff. in M.B. Buch (Ed.), Fifth Survey of Educational Research, NCERT.

[108]. Sharma, V.P. and Bhargava, M. (1980). Academic achievement and prolonged deprivation. Jr of Education and Psychology, Vol. 37 , No. 4.

[109]. Singh, A and Singh, A.K. (2007). Impact of caste and habitat on achievement in mathematics at upper primary level school. Journal of Teacher Education and Research. Vol.2, No.2, Dec.

[110]. Singh, B. (1986). A Study of Some Possible Contributing Factors to High and Low Achievement in Mathematics of the High School Students of Orissa, Ph.D. Edu., Sambalpur Univ.reff. in M.B. Buch (Ed.), Fourth Survey of Educational Research, NCERT.

[111]. Sitha, Chhinh (2003). Effect of Pupil Factor on Mathematics Achievement in Cambodian Urban Primary School. Asia Pacific Education Review, 2003, Vol. 4, No. 2, 151-160.

[112]. Somasundarn, M. (1980). A study of the relationship of school environment and socio-economic status in the formation of geometrical concepts among school children Ph.D. Edu. Guru Ghasidas Univ. ref in Third Survey of Educational Research. NCERT.

[113]. Soundararaja Rao, T.R (1981). A comparative study of academic achievement of pupils of class X in English and composite mathematics. Journal of Educational Research and Extension. Vol. 4, No. 2.

[114]. Sriniwasan (1999). A study of achievement in mathematics standard XIII students of TamilNadu as related to certain selected variables. Ph.D (Edu.). Annamalai Univ.

[115]. Stella, Antony and Purushothaman (1995). Maths study attitude of the underachievers. Experiments in Education, vol. XXIII (1) 3-11

[116]. Strutchen, M.E. (1993). An exploratory study of the societal and ethnic factors affecting sixth grade. African, American student performance in a mathematics class. Ph.D. University of Georgia. cited in Dissertation Abstract International, Vol.54 no.6 Dec. 1993.

[117]. Sucin, Linda. K. (1992). Prediction of success in introducing college mathematics course of Trident Technical college. Ph.D. University of South Carolina. Ref in Dissertation Abstract International, Vol. 53, No. 3, Sept. 1992, p .748A.

[118]. Sumangala, V. (1998). Some psychological variables discriminating between high and low achievers in mathematics. Experiments in Education, Vol. 23 (10\&11), 165-175.

[119]. Teague, Betty Jean (1995). Mathematics achievement and its relationship to career aspirations of eight-grade African. American, Anglo and Hispanic girls. Ph.D. Arizona state university. Ref in Dissertation Abstract International, vol. 56, No. 1, July 1995.

[120]. Testone, S.A. (1992). The effect of different methods of instruction on developmental mathematics students in community wllege. Ph.D. Syracuse University. Ref. In Dissertation Abstract International, Vol. 53, no.12 June.

[121]. Thampurathy, N.R. \& Girija Devi. (1994). Interaction effect of creativity, attitude towards problem solving and social position on the achievement in Mathematics of secondary school pupils. Ph.D., (Edu.) Univ. of Calicut.

[122]. Thomous, K.J. and Wangu, R.S. (1995). Attitude towards and achievement in mathematics among high school students of tribal town of Aizawl. Indian Journal of Psychometry and Education, 26(1), 31-36.

[123]. Toole, C.M. (2001). Exploring math achievement by examining its relationship to ethnic background, gender and level of formal reasoning, Ph.D. University of North Carolina, ref in Dissertation Abstract International. vol 62 No. D-3 p 953A.

[124]. Tsai, shiow-Ling and Walberg, H.J. (1983). Mathematics achievement and attitude productivity in Junior High School. Journal of Educational Research. 76:5, 267-272

[125]. Turner, R.F (1993). An analysis of variables associated with reading and mathematic achievement in grades $4 \& 5$ in the Columbus public school system of Ohio. Ph.D. The Ohio state university. Ref in Dissertation Abstract International, vol. 54, no-5 November 1993.

[126]. Vance, W.R. (1993). A comparison of rational restructuring and anxiety management training as treatment of mathematics anxiety and improving performance in mathematics in college students. Ph.D. Mississippi state University. Ref in Dissertation Abstract International, vol. 53. no. 7, Jan 1993.

[127]. Wang, A.H. (2001). A cross-national investigation of gender difference in mean and variance of mathematics achievement of thirteen year old. Ph.D. University of Pennslylvania. Reff. in Dissertation Abstract International. Vol. 62 No. 2 Aug. 2001.

[128]. Watson, Bannish Judith (1981). Effects of modes on instruction in matrices on the attitude and knowledge of elementary school in service teachers. Dissertation Abstract International, Vol. 42, no. 4, p.1524.

[129]. Wells, B.G. (1996). Overcoming the olds. African American students who in secondary school mathematics. Ph.D. University of California. Ref. in Dissertation Abstract International, Vol. 57, no. 2 Aug. 1996.

[130]. Whang, P.A. (1997). Modling the mathematical achievement of Asian-American elementary students. Learning and individual differences, Vol. 9(1) : 63:88.

[131]. Wohlgehager, K.S. (1992). A comparison of the attitude and achievement in mathematics of algebra students using computer-based instruction and traditional instructional methods. Ph.D. University of North Texas. Ref. In Dissertation Abstract International, Vol. 53, no. 12.

[132]. Wong, N.Y. and Watkins, D. (1998). A longitudinal study at the psycho-social environmental and learning approaches in the Hong-Kong classroom. Journal of Educational Research. Vol. 91(4) : 247-254.

[133]. Yousuf, S.M. and Sinha, A.N. (1983). Behaviour production scale. cited in Agarawal. T. (1998). Psycho-sociogenic cognitive and non-cognitive correlates of academic achievement among special group- An analytical study. Ph.D. (Education) Dayalbagh Educational Institute. Agra. 